\title{
Study of the useful characteristics of the red pigments of Serratia marcescens strains isolated from the soil
}

\author{
Ritasree Mandal, Arindam Adhikari, Gopinath Rana, Tanusri Mandal* \\ Dept. of Biotechnology, Vidyasagar University, Rangamati, West Midnapore- 721102, West Bengal, India.
}

\section{ARTICLE INFO \\ Article history: \\ Received on: $21 / 12 / 2016$ \\ Accepted on: 05/04/2017 \\ Available online: $30 / 08 / 2017$ \\ Key words: \\ Serratia marcescens, Red pigments, prodigiosin, $16 \mathrm{~s}$ rRNA analysis, Antioxidant, Antibacterial.}

\begin{abstract}
Two red pigments have been produced by two different bacterial strains. They have been isolated from soil of West Bengal, India. Upon biochemical and the 16s rRNA analysis, the two strains have been identified as Serratia marcescens by the NCBI (National Center for Biotechnology Information). The GenBank accession number of one of the strains named PNSRR is KU726553. Another one, PNSHR, has the GenBank accession number, KU707218. Maximum red pigment productions have been achieved by optimizing the physical parameter, temperature, and also the chemical parameters, such as $\mathrm{pH}$ and Magnesium Chloride $\left(\mathrm{MgCl}_{2}\right)$ catalyst. The two red pigments have been extracted from two different bacteria by methanol extraction procedure. Those pigments have been identified as prodigiosin, when passed them through HPLC and UV-Vis spectrometry. The Rf values of the extracted pigments have been found to be around 0.88 in the TLC method. The lower $\mathrm{IC}_{50}$ values of the pigments have demonstrated stronger antioxidant activities than the conventional ones, such as ginger, turmeric, and garlic. In addition, they have antibacterial activities against $E$. coli and $K$. pneumoniae. Specifically, the strain, KU726553, has shown strong dye activity, when used in cotton and plastic materials.
\end{abstract}

\section{INTRODUCTION}

Nowadays, natural pigments find their applications in food, pharmaceutical, clothing, plastics, glass, ceramics, and dye industries. Recently, violet pigment named violacein has been reported to have inhibitory activities on protein kinase A (Hosokawa et al., 2016). The biopigments can be extracted from flowers, fruits, vegetables, microorganisms, and others. Using pigments extracted from natural resources are safe and environmental friendly unlike the synthetic pigments, which are generally composed of heavy and toxic metals, such as lead $(\mathrm{Pb})$, chromium (Cr), and cadmium (Cd). In addition, they contain carcinogenic organic compounds. Red, yellow, and blue are the primary natural pigments. Among the pigments, red pigment production is very popular because of its stability and texture in

\footnotetext{
* Corresponding Author

Emai: tanusrimandaloist@gmail.com
}

food, pharmaceutical, and plastic industries. Also, red pigments are in great demand due to its attractiveness in cosmetic, clothing, and ink industries. They have been widely used in lipstick, nail polish, dresses, paints, and pens. Red pigments can be obtained from the easily available sources, such as rose, hibiscus, cherry, and beet. However, we have used biopigments produced by bacteria because of their high growth rate, pigment stability, and feasibility of bioprocess development ( $\mathrm{Lu}$ et al., 2009). In this study, two different bacterial strains of Serratia marcescens have been isolated from the soil of West Bengal, India. The bacterial strains have been observed to produce two chemically different red pigments called prodigiosin along with its derivatives. All prodigiosin pigments have pyrrolyldipyrromethene core structures (Rapoport and Holden, 1962). Various composition media and incubation conditions have been used to optimize the production of the two red pigments (Cho et al., 2002). The production rates depend on various factors, such as species type, incubation time, temperature, $\mathrm{pH}$, carbon and nitrogen sources, and inorganic salts (Kim et al., 2009; Pandey et al., 2009). 
In addition, nutrient broth (Pryce and Terry, 2000) and peptone glycerol broth (Hiroaki et al., 1996) have been used to accelerate pigment productions.

The pigment, prodigiosin, first isolated from Serratia marcescens (Gerber, 1975) has been reported to have wide varieties of useful biological activities. It has been used as antibacterial, antifungal, antimalarial, immunosuppressive, and anticancer drugs (Montaner and P'erez-Tom'as, 2003; Williamson et al., 2007). Hence, antioxidant, antibacterial, and dye activities of the two red pigments have been examined in this paper.

\section{MATERIALS AND METHOD}

\section{Isolation of microorganism}

Rhizospheric soils of two different herbs have been selected to isolate pigment producing bacteria. The two different selected soils have been separately serially diluted up to $10^{8}$ dilutions and spread on nutrient agar (NA) plates. The plates have been incubated for 72 hours at $25^{\circ} \mathrm{C}$. After incubation, red pigmented colonies have been transferred on fresh plates. The pure cultures prepared from those fresh plates have been used for further studies.

\section{Biochemical characterization}

Gram staining and other biochemical tests have been performed according to Bergey's manual (Boone and Castenholz, 2012) to find the characteristics of the two red pigmented bacteria named as PNSRR and PNSHR.

\section{6s rRNA analysis}

Single colonies have been isolated and cultured in Luria Bertani (LB) (Sezonov et al., 2007) broth media for the two red pigments for three days at $25^{\circ} \mathrm{C}$ for maximum growth of bacteria. The media has been prepared with tryptone, yeast extract, and sodium chloride and supplemented with peptone. Genomic DNA of the two bacteria, PNSRR and PNSHR, have been isolated by proper protocol and their DNA have been sequenced by the company, Xcelris, Ahmadabad, India. The GenBank accession numbers of the strains PNSRR and PNSHR have been identified as KU726553 and KU707218, respectively.

\section{Enhancing pigment production optimizing media composition}

Four sets of culture media have been prepared with $1 \mathrm{~g}$

$\mathrm{NaCl}, 1 \mathrm{~g}$ tryptone, $0.5 \mathrm{~g}$ yeast extract, $0.5 \mathrm{~g}$ peptone, and dissolved in $100 \mathrm{ml}$ distilled water for the two red pigment producing bacteria, PNSRR and PNSHR. Furthermore, various inorganic salts, such as $\mathrm{MgCl}_{2}, \mathrm{CaCl}_{2}, \mathrm{NaCl}$, and $\mathrm{KCl}(\mathrm{Lu}$ et al., 2009) have been selected for their catalytic activities. Each set of the four media has been supplemented with exactly one of the inorganic salts, $\mathrm{MgCl}_{2}, \mathrm{CaCl}_{2}, \mathrm{NaCl}$, or $\mathrm{KCl}$.

That has been done to obtain maximum growth of the bacteria, maximum pigment production, and observe catalytic effects. The amount of the salts used in the media has been equivalent to the amount of the salts present in the surface water according to the World Health Organization (WHO). In addition, the physical parameters, such as incubation time and temperature and the chemical parameter, $\mathrm{pH}$, have been optimized for best cell growth and pigment production. Temperature has been maintained between $20^{\circ}-40^{\circ} \mathrm{C}$ and incubation time has been fixed from 1-7 days. The $\mathrm{pH}$ value has been adjusted at 7.5.

Growth kinetics has been carried out at $660 \mathrm{~nm}$ for 0-36 hours. The inoculum has been prepared for pure culture by transferring $1 \mathrm{ml}$ of bacterial culture with $18 \mathrm{hrs}$ incubation time at the logarithmic phase of growth having an optical density value of 1.0 at $660 \mathrm{~nm}$.

\section{Extraction and purification of the pigments}

The bacteria, PNSRR and PNSHR, secrete extracellular red pigments. Thus, $60 \%$ methanol solution has been added into the two different bacterial solutions to extract total red pigment solutions from the two strains. The addition of methanol causes bursts of bacterial cells to release intercellular pigments. The entire solutions containing pigment solutions and bacterial masses of PNSRR and PNSHR have been separately subjected to centrifugation at $10,000 \mathrm{rpm}$ for 10 minutes. Then, the supernatants containing the pigments of PNSRR and PNSHR have been collected for purification.

The purification has been performed by two different methods, Silica gel bedded column and HPLC. In the first method, the supernatants of PNSRR and PNSHR have been separately subjected to pass through silica gel bedded column. Then, methanol has been used as the eluting solvent.

In the second method of purification, HPLC has been performed for both the pigment solutions using the model Waters 600 equipped with UV-Vis detector. Both the solutions have been run for 15 minutes. It has been done to find different components of the pigment solutions. The $\mathrm{C} 18$ reverse phase column has been used as the separating column. The operating temperature has been maintained at $25{ }^{\circ} \mathrm{C}$. Furthermore, an injecting volume of $20 \mu \mathrm{l}$ of each pigment solution along with $60 \%$ methanol as the mobile phase with a flow rate of $1 \mathrm{ml} /$ minute has been used.

\section{UV-Vis spectrometric analysis of the pigments}

The purified red pigment solutions have been analysed by the UV-Vis Spectrometry with $200-700 \mathrm{~nm}$ ranges of wavelengths of light. It has been done to find the maximum absorption peaks of the pigments. The specification of the instrument has been UV-3600 Shimadzu, UV Vis NIR spectrophotometer; model TCC-240A.

\section{Antibacterial activities of the pigments}

The antibacterial activities of the two red pigments have been performed according to Vora et al., (2014), with some modifications. Four NA plates have been taken for each red pigment. Four pathogenic bacteria, Escherichia coli, Klebsiella pneumoniae, Bacillus subtilis, and Salmonella typhi have been selected to determine the antibacterial capabilities of the two red pigments. A $500 \mu \mathrm{l}$ pathogenic solution of each selected bacterium 
has been separately spread on the two corresponding NA plates of the two red pigments. Then, three sterile filter papers of diameter 5 mm have been placed on each NA plate containing the respective pathogenic solution. Prior to placing the sterile papers on the NA plates, the first one has been impregnated with the respective red pigment solution; the second and the third sterile papers have been dipped in $95 \%$ methanol solution and $1 \mathrm{mg} / \mathrm{ml}$ erythromycin, respectively.

The methanol solution has been taken as the negative control and the erythromycin solution has been taken as the positive control. After completion of the setup, all the plates have been kept for incubation at $25^{\circ} \mathrm{C}$ for $24 \mathrm{hrs}$.

\section{Antioxidant activities of the pigments}

The antioxidant activities of the two red pigments have been assessed qualitatively and quantitatively. The free radical scavenging activity of 2, 2-diphenyl-1-picrylhydrazyl (DPPH) has been used for both quantitative and qualitative testing purposes. The qualitative tests have been conducted as describe by Biswas et al (2014), with some modifications.

In the qualitative estimation, commercially available thin layer chromatography plates have been used. Drops of the red pigments have been placed on the plates. Those plates have been dipped in solutions containing methanol, chloroform, and hexane in the ratio of 7:3:1 and air dried after sometime. Furthermore, a dark violet solution of DPPH has been prepared with $0.05 \%$ DPPH in methanol and spread on the dried TLC plates. Pale yellow colour has been observed to develop on the plates because of the antioxidant activities of the pigments. Vitamin $\mathrm{C}$ has been taken as the control.

In the quantitative estimation, a standard curve of vitamin $\mathrm{C}$ has been prepared by taking various concentrations ( 0 100ppm) from the stock solutions of Vitamin C. $2 \mathrm{ml}$ solution of each red pigment has been taken, mixed with $0.05 \%$ methanol solution of DPPH, and incubated for 30 minutes at room temperature. The optical densities of PNSRR and PNSHR have been measured at $517 \mathrm{~nm}$ using UV-Vis spectrometry. The inhibition ratio has been calculated by the following formula:

$$
\% \text { Inhibition }=\left(\frac{\text { Blank } O D-\text { Sample } O D}{\text { Blank } O D}\right) * 100
$$

\section{Dye Activities of the pigments}

The dyeing capabilities of the two red pigments have been examined. The experiments have been performed as described by Shahitha et al, 2012, with some modifications. Cotton pieces and plastic sheets have been dipped in $20 \mathrm{ml}$ solutions of each red pigment. The cotton pieces have been allowed to boil for 15 minutes and the plastic sheets have been kept in hot red pigment solutions. Then, the cotton pieces and the plastic sheets have been kept for air drying at room temperature. It has been observed that only the cotton pieces and the plastic sheets dipped in the strain, KU726553, retained strong red colour. After drying those cotton pieces and plastic sheets, they have been washed off with ethanol for removal of loosely attached pigment particles.

\section{RESULTS AND DISCUSSION}

\section{Biochemical characterization of bacteria}

The Gram staining of the strains PNSRR and PNSHR have revealed that they are Gram negative and small rod shaped in nature. Biochemical characterizations of PNSRR and PNSHR have shown that the strains can produce indole acetic acid, one of the main hormones promoting plant growth. It has been tested that PNSRR cannot utilize starch in media, but can produce oxidase, and catalase enzyme, whereas PNSHR has tested negative for all the three. The detailed results have been tabulated in Table 1.

Table 1: Biochemical characteristics of PNSRR and PNSHR

\begin{tabular}{ccc}
\hline Biochemical Tests & PNSRR & PNSHR \\
\hline MR & + & + \\
VP & - & - \\
IAA & + & + \\
Citrate & + & + \\
Catalase & + & - \\
Oxidase & + & - \\
Nitrate & - & - \\
Gelatin & + & + \\
Urease & + & + \\
Starch & - & - \\
Ammonia & - & + \\
Phosphate & - & - \\
\hline
\end{tabular}

\section{6s rRNA analysis of bacteria}

The strains, PNSRR and PNSHR, have been deposited at the GenBank database with accession numbers KU726553 and KU707218, respectively. The phylogenetic trees of PNSRR and PNSHR have been shown in Fig. 1 (a) and Fig. 1 (b), respectively.

\section{Enhancing pigment production optimizing media composition}

The growth curves of PNSRR and PNSHR have been observed from 0-48 hours of incubation. The logarithmic phase of PNSRR has been started from the $7^{\text {th }}$ hour and continued up to the $25^{\text {th }}$ hour of incubation. The highest peak has been observed at $25^{\text {th }}$ hour and the optical density has been recorded at 1.13 . In case of PNSHR, the log phase has been started at the $10^{\text {th }}$ hour and the optimum growth has been observed at $25^{\text {th }}$ hour with optical density value at 1.12 .

After five days of incubation with appropriate temperature and media composition, bacterial growths and pigment productions of PNSRR and PNSHR attained maximum values. After completion of the growth curve experiments, dry weights of the pigments have been measured. Among the selected salts, $\mathrm{MgCl}_{2}$ has been observed to have the best effect on cell growths and pigment productions. The optimum temperatures for the maximum cell growths of PNSRR and PNSHR have been observed to be around $25{ }^{\circ} \mathrm{C}$. The detailed results of pigment productions of PNSRR and PNSHR have been tabulated in Table 2 and Table 3, respectively. 


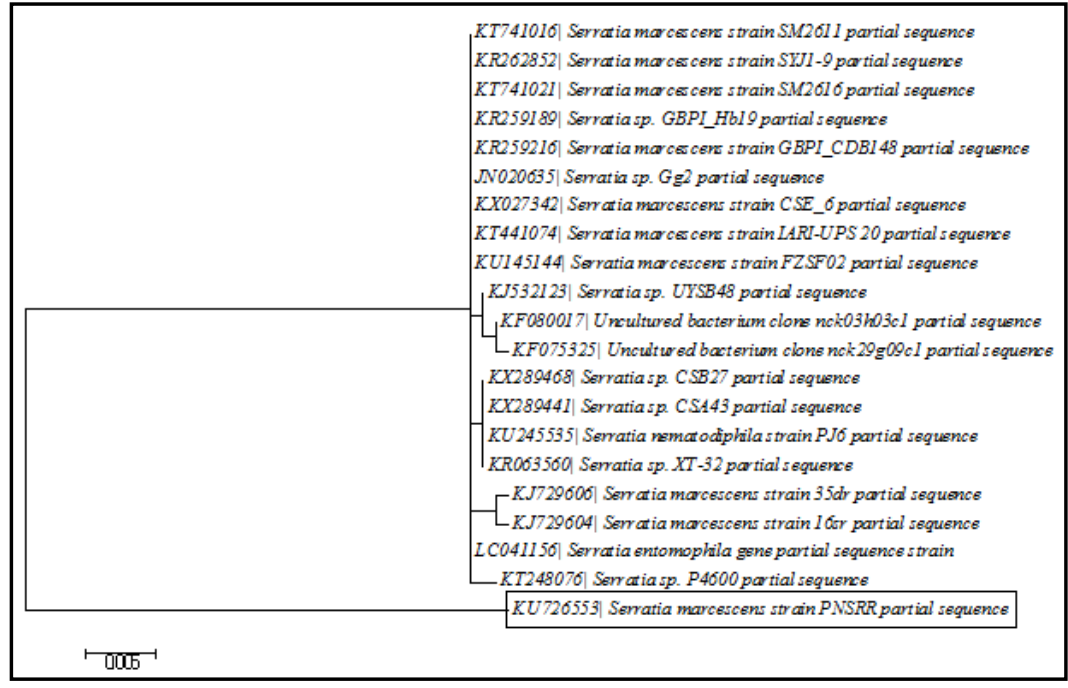

Fig. 1 (a): Phylogenetic tree of PNSRR.

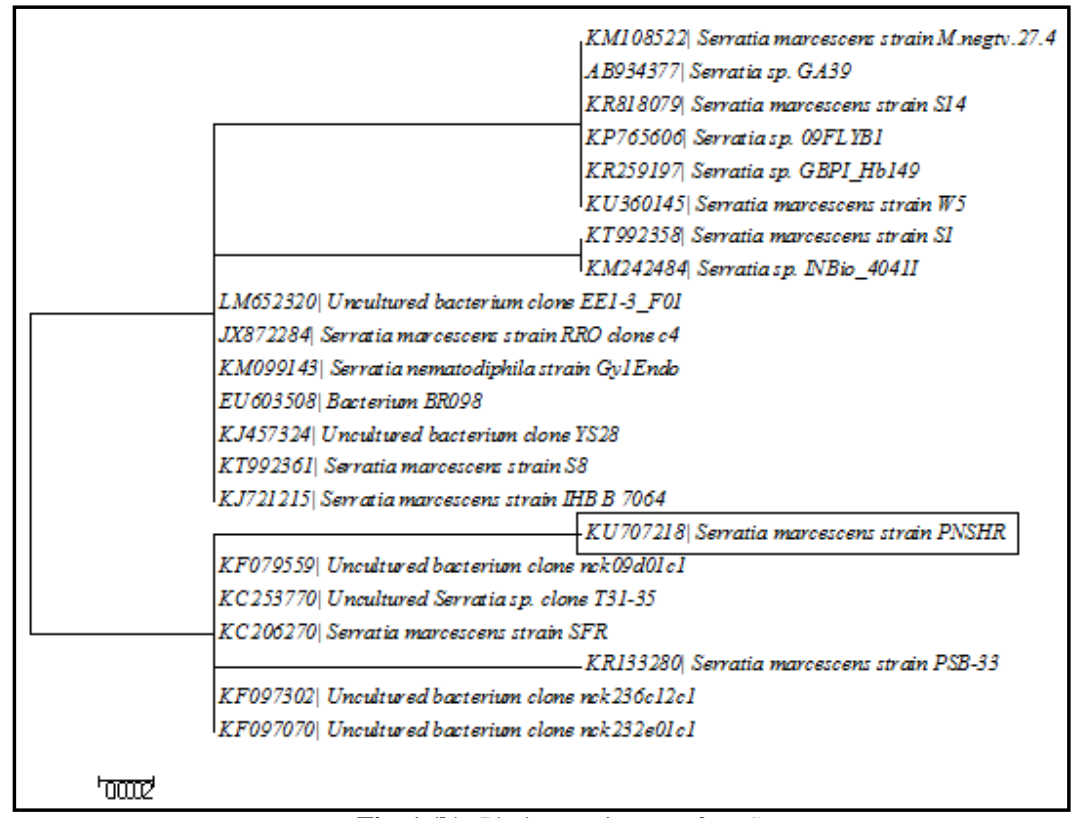

Fig. 1 (b): Phylogenetic tree of PNSHR

Table 2: Pigment production of PNSRR.

\begin{tabular}{|c|c|c|c|c|c|}
\hline Days & Media without salts & Media with $\mathrm{CaCl}_{2}$ & Media with NaCl & Media with KCl & Media with $\mathrm{MgCl}_{2}$ \\
\hline 1 & $0 \mathrm{~g} / 100 \mathrm{ml}$ & $0 \mathrm{~g} / 100 \mathrm{ml}$ & $0 \mathrm{~g} / 100 \mathrm{ml}$ & $0 \mathrm{~g} / 100 \mathrm{ml}$ & $0.101 \mathrm{~g} / 100 \mathrm{ml}$ \\
\hline 2 & $0.032 \mathrm{~g} / 100 \mathrm{ml}$ & $0.024 \mathrm{~g} / 100 \mathrm{ml}$ & $0.034 \mathrm{~g} / 100 \mathrm{ml}$ & $0.010 \mathrm{~g} / 100 \mathrm{ml}$ & $0.256 \mathrm{~g} / 100 \mathrm{ml}$ \\
\hline 3 & $0.094 \mathrm{~g} / 100 \mathrm{ml}$ & $0.081 \mathrm{~g} / 100 \mathrm{ml}$ & $0.097 \mathrm{~g} / 100 \mathrm{ml}$ & $0.051 \mathrm{~g} / 100 \mathrm{ml}$ & $0.398 \mathrm{~g} / 100 \mathrm{ml}$ \\
\hline 4 & $0.151 \mathrm{~g} / 100 \mathrm{ml}$ & $0.142 \mathrm{~g} / 100 \mathrm{ml}$ & $0.160 \mathrm{~g} / 100 \mathrm{ml}$ & $0.131 \mathrm{~g} / 100 \mathrm{ml}$ & $0.565 \mathrm{~g} / 100 \mathrm{ml}$ \\
\hline 5 & $0.2 \mathrm{~g} / 100 \mathrm{ml}$ & $0.19 \mathrm{~g} / 100 \mathrm{ml}$ & $0.208 \mathrm{~g} / 100 \mathrm{ml}$ & $0.15 \mathrm{~g} / 100 \mathrm{ml}$ & $0.677 \mathrm{~g} / 100 \mathrm{ml}$ \\
\hline 6 & $0.182 \mathrm{~g} / 100 \mathrm{ml}$ & $0.174 \mathrm{~g} / 100 \mathrm{ml}$ & $0.191 \mathrm{~g} / 100 \mathrm{ml}$ & $0.142 \mathrm{~g} / 100 \mathrm{ml}$ & $0.581 \mathrm{~g} / 100 \mathrm{ml}$ \\
\hline 7 & $0.160 \mathrm{~g} / 100 \mathrm{ml}$ & $0.154 \mathrm{~g} / 100 \mathrm{ml}$ & $0.179 \mathrm{~g} / 100 \mathrm{ml}$ & $0.121 \mathrm{~g} / 100 \mathrm{ml}$ & $0.502 \mathrm{~g} / 100 \mathrm{ml}$ \\
\hline
\end{tabular}

Table 3: Pigment production of PNSHR.

\begin{tabular}{|c|c|c|c|c|c|}
\hline Days & Media without salts & Media with $\mathrm{CaCl}_{2}$ & Media with NaCl & Media with KCl & Media with $\mathrm{MgCl}_{2}$ \\
\hline 1 & $0 \mathrm{~g} / 100 \mathrm{ml}$ & $0 \mathrm{~g} / 100 \mathrm{ml}$ & $0 \mathrm{~g} / 100 \mathrm{ml}$ & $0 \mathrm{~g} / 100 \mathrm{ml}$ & $0 \mathrm{~g} / 100 \mathrm{ml}$ \\
\hline 2 & $0.029 \mathrm{~g} / 100 \mathrm{ml}$ & $0.020 \mathrm{~g} / 100 \mathrm{ml}$ & $0.030 \mathrm{~g} / 100 \mathrm{ml}$ & $0.009 \mathrm{~g} / 100 \mathrm{ml}$ & $0.250 \mathrm{~g} / 100 \mathrm{ml}$ \\
\hline 3 & $0.090 \mathrm{~g} / 100 \mathrm{ml}$ & $0.077 \mathrm{~g} / 100 \mathrm{ml}$ & $0.095 \mathrm{~g} / 100 \mathrm{ml}$ & $0.045 \mathrm{~g} / 100 \mathrm{ml}$ & $0.390 \mathrm{~g} / 100 \mathrm{ml}$ \\
\hline 4 & $0.146 \mathrm{~g} / 100 \mathrm{ml}$ & $0.136 \mathrm{~g} / 100 \mathrm{ml}$ & $0.153 \mathrm{~g} / 100 \mathrm{ml}$ & $0.120 \mathrm{~g} / 100 \mathrm{ml}$ & $0.558 \mathrm{~g} / 100 \mathrm{ml}$ \\
\hline 5 & $0.189 \mathrm{~g} / 100 \mathrm{ml}$ & $0.184 \mathrm{~g} / 100 \mathrm{ml}$ & $0.199 \mathrm{~g} / 100 \mathrm{ml}$ & $0.143 \mathrm{~g} / 100 \mathrm{ml}$ & $0.665 \mathrm{~g} / 100 \mathrm{ml}$ \\
\hline 6 & $0.173 \mathrm{~g} / 100 \mathrm{ml}$ & $0.169 \mathrm{~g} / 100 \mathrm{ml}$ & $0.182 \mathrm{~g} / 100 \mathrm{ml}$ & $0.131 \mathrm{~g} / 100 \mathrm{ml}$ & $0.570 \mathrm{~g} / 100 \mathrm{ml}$ \\
\hline 7 & $0.151 \mathrm{~g} / 100 \mathrm{ml}$ & $0.148 \mathrm{~g} / 100 \mathrm{ml}$ & $0.171 \mathrm{~g} / 100 \mathrm{ml}$ & $0.115 \mathrm{~g} / 100 \mathrm{ml}$ & $0.491 \mathrm{~g} / 100 \mathrm{ml}$ \\
\hline
\end{tabular}




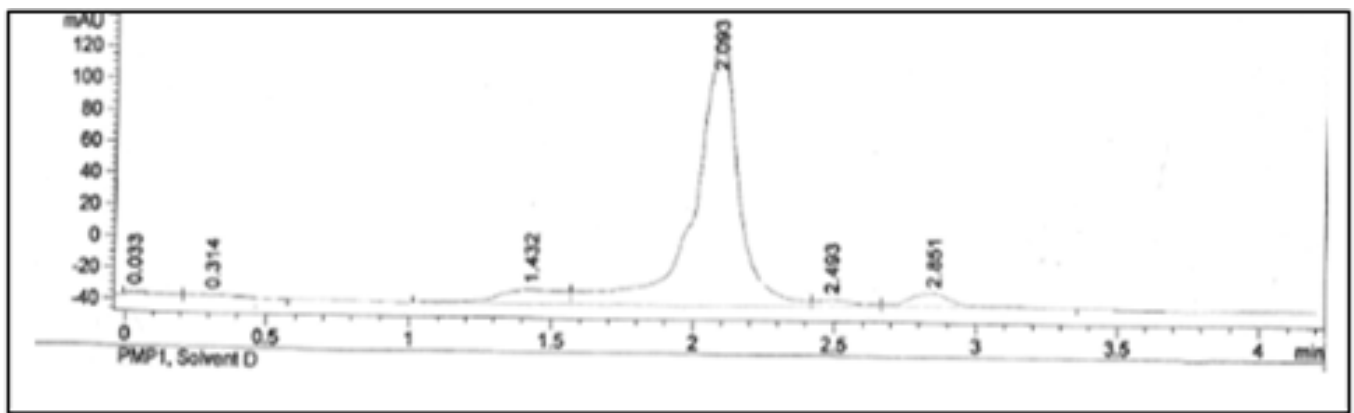

Fig. 2: HPLC chromatogram of the red pigment of PNSRR.

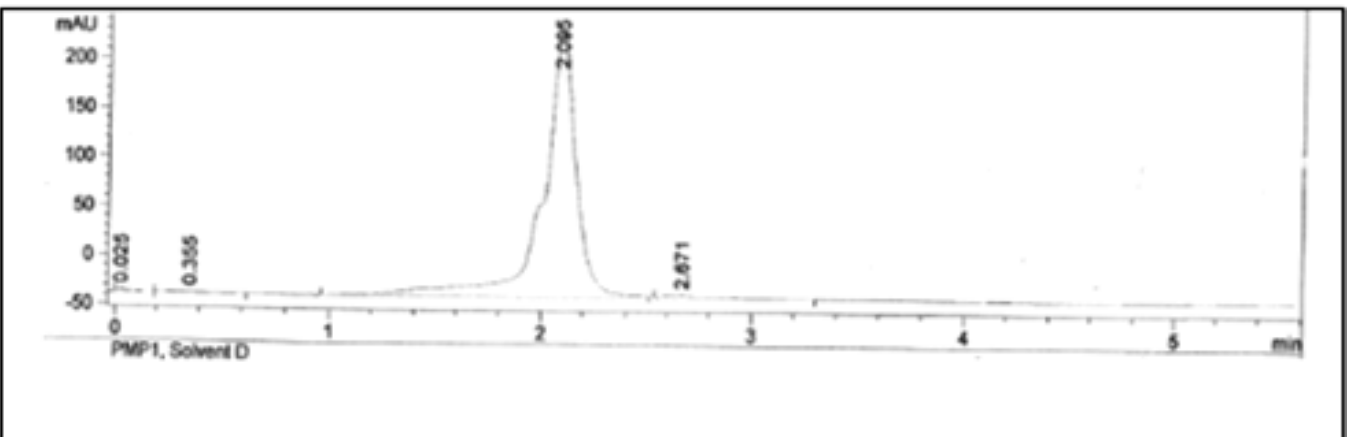

Fig. 3: HPLC chromatogram of the red pigment of $P N S H R$.

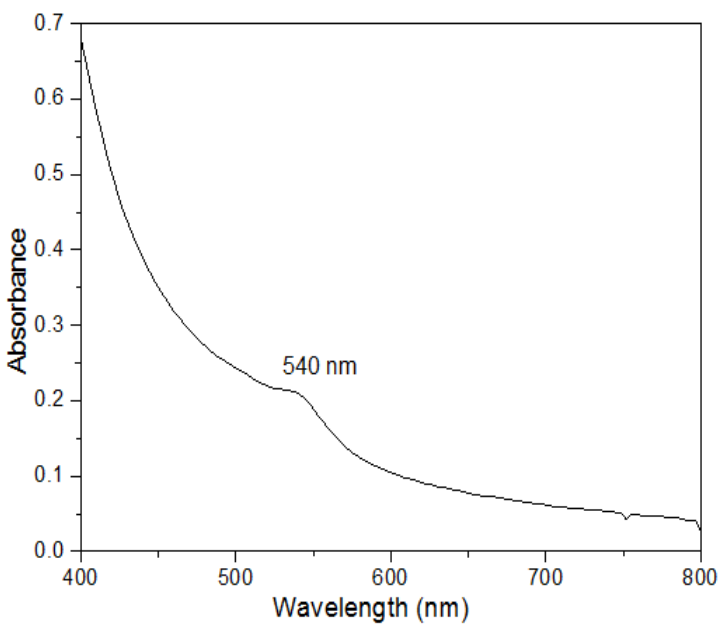

Fig. 4: UV-Vis spectrum of the red pigment of PNSRR.

\section{Extraction and purification of the pigments}

The HPLC experiments have been conducted for 15 minutes. The main peaks of the samples have been observed after 2 minutes of sample injection. The retention times, until 4 minutes, of the samples have been shown in the Fig. 2 and Fig.3. No sharp peaks have been observed after 4 minutes.

\section{UV-Vis Spectrometric analysis of the pigments}

The purified red pigment solutions of both the bacteria, PNSRR and PNSHR, have been run from 200 to $700 \mathrm{~nm}$ ranges of wavelengths in UV-Vis spectrophotometer. The maximum absorption peaks of visible light have been detected at

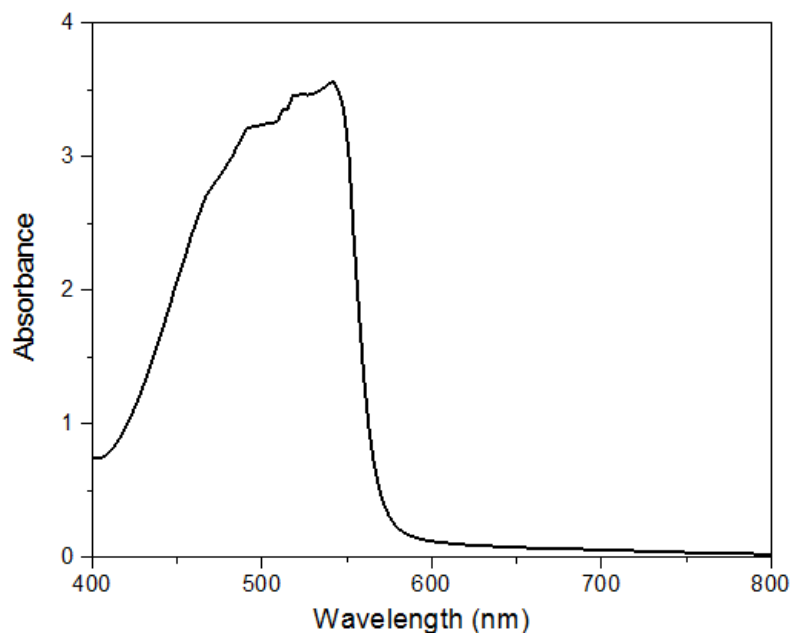

Fig. 5: UV-Vis spectrum of the red pigment of PNSHR.

$540 \mathrm{~nm}$ and $541 \mathrm{~nm}$ for PNSRR and PNSHR, respectively. The absorption peaks at $540 \mathrm{~nm}$ and $541 \mathrm{~nm}$ have been found to be equivalent to the maximum absorption peak of prodigiosin (Kumar and Aparna, 2014). The chromatograms of both pigments have been shown in Fig. 4 and Fig. 5.

\section{Antibacterial activities of the pigments}

It has been observed that the red pigment from PNSRR has good antibacterial activity against Escherichia coli and moderate activity against Klebsiella pneumoniae. In case of PNSHR, the respective extracted pigment can strongly inhibit the growth of Klebsiella pneumoniae and moderately inhibit the 
growth of Escherichia coli. Tetracycline has been taken as the positive control and methanol as the negative control. Detailed results have been tabulated in Table 4 .

Table 4: Antibacterial activities of the red pigments.

\begin{tabular}{lclll}
\hline \multicolumn{1}{c}{ Pathogenic bacteria } & $\begin{array}{c}\text { Positive } \\
\text { control }\end{array}$ & $\begin{array}{c}\text { Negative } \\
\text { control }\end{array}$ & PNSRR & PNSHR \\
\hline Escherichia coli & $2.3 \mathrm{~cm}$ & $0 \mathrm{~cm}$ & $2.1 \mathrm{~cm}$ & $1.7 \mathrm{~cm}$ \\
Bacillus subtilis & $1.1 \mathrm{~cm}$ & $0 \mathrm{~cm}$ & $0.2 \mathrm{~cm}$ & $0.01 \mathrm{~cm}$ \\
Salmonella typhi & $1.5 \mathrm{~cm}$ & $0 \mathrm{~cm}$ & $0.3 \mathrm{~cm}$ & $1.3 \mathrm{~cm}$ \\
Klebsiella pneumoniae & $1.9 \mathrm{~cm}$ & $0 \mathrm{~cm}$ & $1.1 \mathrm{~cm}$ & $3.0 \mathrm{~cm}$ \\
\hline
\end{tabular}

\section{Antioxidant activities of the pigments}

In the qualitative analysis, the $\mathrm{Rf}$ values of both the pigments have been found to be around 1.22. It is similar to the standard one, Vitamin C. Hence, it can be concluded that the pigments have antioxidant capabilities, which have properties similar to Vitamin C. In the quantitative analysis, a standard curve of percentage of inhibition has been plotted against the concentrations (0-100ppm) of Vitamin C (control). Along with the standard curve, results of the samples taken in the same concentration as the standard one have also been plotted.

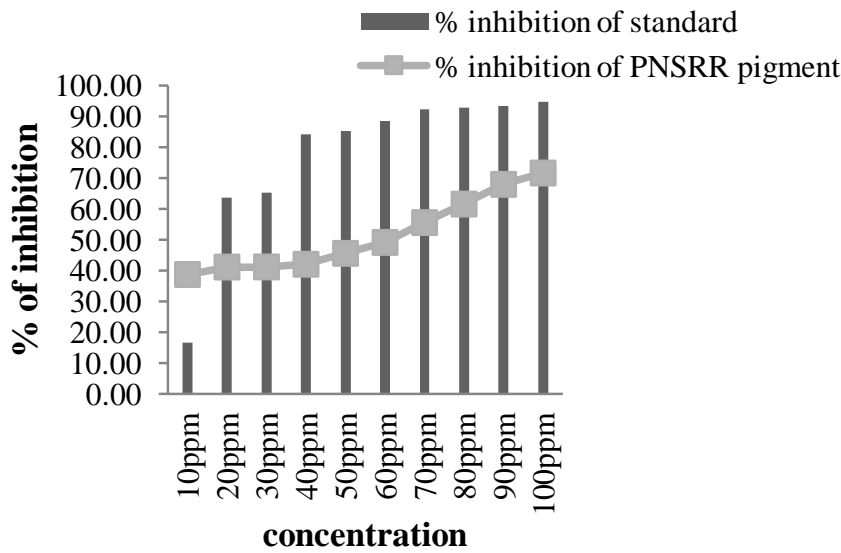

Fig. 6: DPPH scavenging activity of the red pigment of PNSRR (\% inhibition Vs concentration)

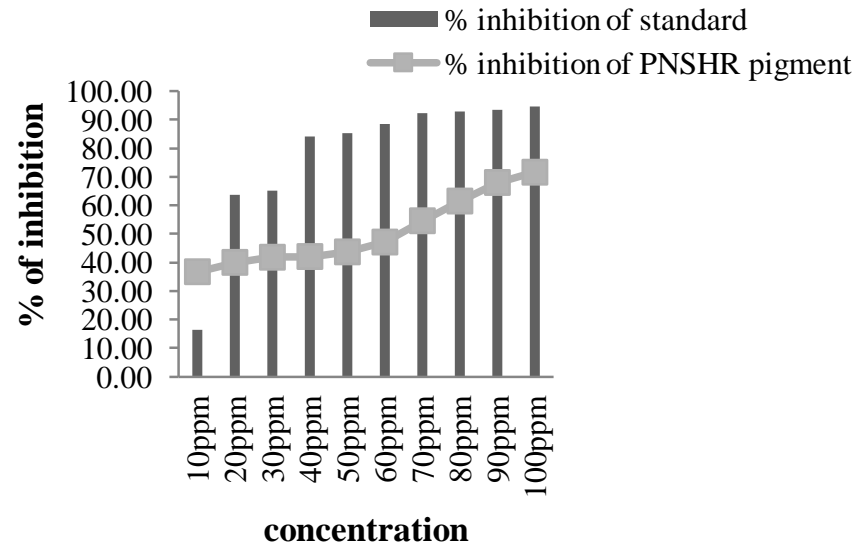

Fig.7: DPPH scavenging activity of the red pigment of PNSHR (\% inhibition Vs concentration).

The $\mathrm{IC}_{50}$ value of the standard has been found to be 12.69. The $\mathrm{IC}_{50}$ values of the pigments of PNSRR and PNSHR have been calculated to be around 51.20 and 53.26, respectively. The DPPH free radical scavenging activities of the pigments have been shown in Fig. 6 and Fig. 7. The comparatively lower $\mathrm{IC}_{50}$ values of the pigments (Fig. 8) have indicated higher antioxidant activities than the conventional antioxidants, such as ginger, turmeric, and garlic (Panpatil et al., 2013).

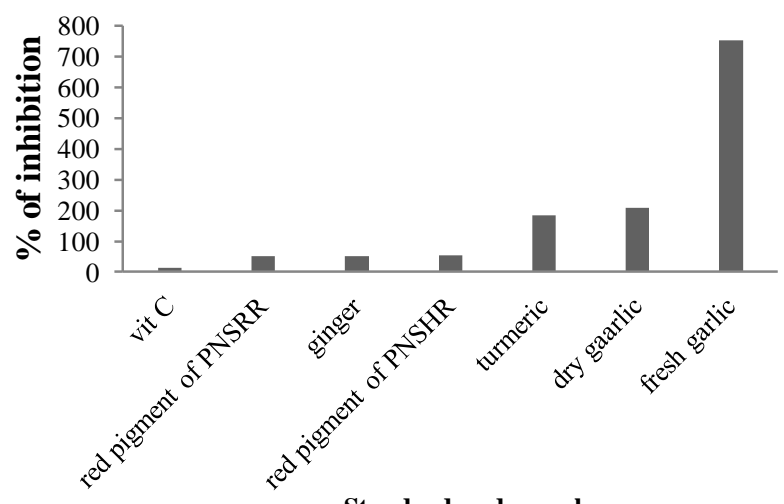

Standard and samples

Fig. 8: Comparison of \% inhibition of DPPH radical scavenging activities of Vitamin $\mathrm{C}$, ginger, turmeric, garlic, and the two red pigments.

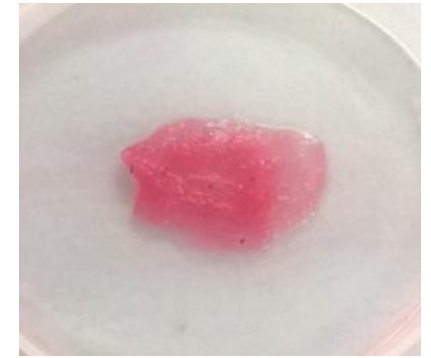

(a)

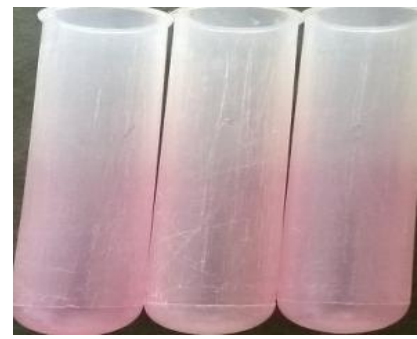

(c)

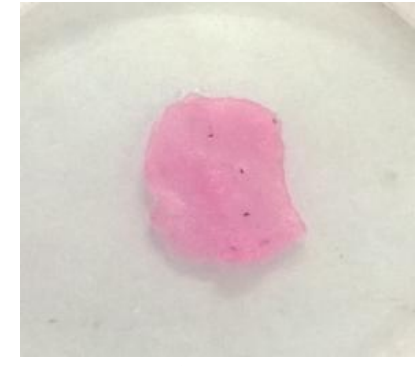

(b)

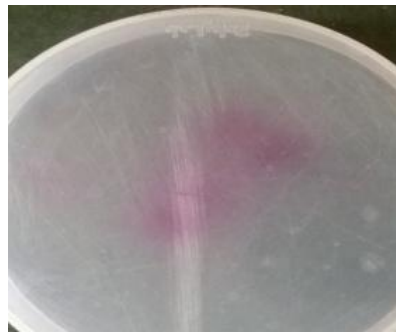

(d)
Fig. 9: (a) shows the cotton just before ethanol washes and (b) represents the cotton after ethanol wash and drying. 9 (c) and 9 (d) are figures of some plastic compounds tightly bounded with the pigment.

\section{Dye Activity of the pigment}

The cotton pieces have been observed to retain the colour of the pigment after they have been treated with the pigment of PNSRR. In addition, the cotton pieces have been washed with ethanol to remove loosely bound pigment particles. The pigment of PNSRR has also been tested with plastic compounds, such as plastic sheets and culture tubes. Furthermore, the plastic materials have been washed with acidic solutions of hydrochloric acid, nitric acid, and sulphuric acid and alkaline solutions of sodium hydroxide and potassium hydroxide. The plastic sheets and culture 
tubes have been observed to retain the pigment colour. Fig. 9 (a), Fig. 9 (b), Fig. 9 (c), and Fig. 9 (d) have shown the results of the pigment of PNSRR acting as a dyeing agent. The colours shown in the Fig. 9 (c) and Fig. 9 (d) are older than one year.

\section{CONCLUSION}

In conclusion, the bacterial strains, Serratia marcescens strain PNSRR and Serratia marcescens strain PNSHR, can produce red coloured pigments. The culture media of the bacteria supplemented with $\mathrm{MgCl}_{2}$ salt and optimum incubation time and temperature at $25^{\circ} \mathrm{C}$ can influence the bacterial growth and maximum pigment production. The two red biopigments neither cause health hazards nor contain toxic compounds. Hence, they can be safely used in food, pharmaceutical, plastic, and dye industries. The pigments have been observed to possess various bioactivities, such as antibacterial and antioxidant activities. The results in this study have demonstrated that the red pigments have stronger antioxidant and antibacterial capabilities than the other conventional sources of antioxidant and antibacterial agents. The natural red pigment produced by PNSRR strain can be used as dyeing agent for cotton and plastic materials as indicated by the experimental results.

In the future, we aim to examine more physical and chemical properties of the two red pigments. The goal would be to utilize the natural red pigments in cosmetic, ink, ceramic, and glass industries.

\section{ACKNOWLEDGEMNET}

The authors would like to thank Ms. Sreyasree Mandal for her thorough and extensive work on the paper for its language, mechanics, grammar, and sentence constructions, organization, and transitions. Also, Dr. N.K. Mandal has added valuable critics and suggestions to the paper. The authors would also like to thank Mr. Manas Mandal, Mr. Partha Pratim Bose, and Mr. Subrata Maikap for actively participating and helping out with the experiments. No funding source has been involved in this research work.

\section{CONFLICT OF INTEREST}

All authors declare that they have no conflict of interests.

\section{REFERENCES}

Biswas NN, Saha S, Ali MK. Antioxidant, antimicrobial, cytotoxic and analgesic activities of ethanolic extract of Mentha arvensis L. Asian Pac. J. Trop. Biomed., 2014; 4: 792-798.
Boone DR, Castenholz RW. Bergey's manual of systematic bacteriology: Volume One: The archaea and the deeply branching and phototrophic bacteria springer science \& business media, USA, 2012.

Cho YJ, Park JP, Hwang HJ, Kim SW, Choi JW, Yun JW. Production of red pigment by submerged culture of Paecilomyces sinclairii. Lett. Appl. Microbiol., 2002; 3: 195-202.

Gerber NN. Prodigiosin-like pigments. Crit. Rev. Microbiol., 1975; 3: 469-485.

Hiroaki M, Hiroyuki A, Masakatsu F, Takeji S, Teisuya T. Industrial production of optically active intermediate in the synthesis of dialtizem with lipase. Seibutsu Kogaku., 1996; 74: 273-288.

Hosokawa K, Soliev AB, Kajihara A, Enomoto K. Effects of a microbial pigment violacein on the activities of protein kinases. Cognet Biology, 2016; 2.

Kim SJ, Lee HK, Yim JH. Statistical optimization of medium components for the production of prodigiosin by Hahella chejuensis KCTC 2396. J. Microbiol. Biotechnol., 2009; 18: 1903-1907.

Kumar TS, Aparna H. Anti-biofouling activity of Prodigiosin, a pigment extracted from Serratia marcescens. Int. J. Curr. Microbiol. App. Sci., 2014; 3: 712-725.

Lu Y, Wang L, Xue Y, Zhang C, Xing XH, Lou K, Zhang Z, Li Y, Zhang G, Bi J, Su Z. Production of violet pigment by a newly isolated psychrotrophic bacterium from a glacier in Xinjiang, China. Biochem. Eng. J., 2009; 43: 135-141.

Montaner B, P'erez-Tom'as R. The prodigiosins: a new family of anticancer drugs. Curr. Cancer Drug Targets, 2003; 3: 57-65.

Pandey R, Chander R, Sainis KB. Prodigiosin as anti cancer agents: Living upto their name. Curr. Pharm. Des., 2009; 15: 732-741.

Panpatil VV, Tattari S, Kota N, Nimgulkar C, Polasa K. In vitro evaluation on antioxidant and antimicrobial activity of spice extracts of ginger, turmeric and garlic. J. Pharmacogn. Phytochem., 2013; 2: 143-148.

Pryce LH, Terry FW. Spectrophotometric assay of gene expression: Serratia marcescens pigmentation. Bioscene, 2000; 26: 3-13.

Rapoport H, Holden KG. The synthesis of prodigiosin. J. Am. Chem. Soc., 1962; 84: 635-642.

Sezonov G, Joseleau-Petit D, D'Ari R. Escherichia coli physiology in Luria-Bertani broth. J. Bacteriol., 2007; 189: 8746-8749.

Shahitha S, Poornima K. Enhanced production of prodigiosin production in Serratia marcescens. J. App. Pharm. Sci., 2012; 2: 138-140.

Vora JU, Jain NK, Modi HA. Extraction, Characterization and Application studies of red pigment of halophile Serratia marcescens KH1R KM035849 isolated from Kharaghoda soil. Int. J. Pure App. Biosci., 2014; 2: 160-168.

Williamson NR, Fineran PC, Gristwood T, Chawrai SR, Leeper FJ, Salmond GPC. Anticancer and immunosuppressive properties of bacterial prodiginines. Future Microbiol., 2007; 2: 605-618.

\section{How to cite this article:}

Mandal R, Adhikari A, Rana G, Mandal R. Study of the useful characteristics of the red pigments of Serratia marcescens strains isolated from the soil. J App Pharm Sci, 2017; 7 (08): 142-148. 